Waldemar Kozyra (Lublin)

\title{
Polityka administracyjna \\ ministrów spraw wewnętrznych Polski Niepodległej w zakresie zdrowia publicznego (1918-1939)
}

1. Przez politykę administracyjną rozumiemy odwołującą się do racjonalnych założeń programową działalność organów administracji publicznej, realizowaną w prawnie dozwolonych formach i sposobach działania. Na politykę tę zasadniczy wpływ ma czynnik pozaprawny, jakim jest ogólnie rozumiane życie polityczne kraju. Poszczególne fazy tej polityki odpowiadają okresom dziejowym charakterystycznym dla historii politycznej danego kraju. Fazy te występują w istocie niezależnie od tego, czy obowiązuje dotychczasowe ustawodawstwo, czy też ulega ono sukcesywnym zmianom i przekształceniom ${ }^{1}$.

W latach 1918-1926 koncepcja polityki administracyjnej resortu spraw wewnętrznych zakładała, że kompetencje urzędu ministra spraw wewnętrznych powinny być realizowane jedynie pod kątem spraw bezpieczeństwa wewnętrznego i porządku publicznego w państwie. W konsekwencji zagadnienia społeczno-polityczne kraju i sprawy stricte administracyjne (m.in. zdrowia publicznego) analizowano przez pryzmat ich bezpośredniego wpływu na stan zagrożenia bezpieczeństwa i porządku publicznego ${ }^{2}$.

Zagadnienia zdrowia publicznego znalazły się w gestii urzędu ministra spraw wewnętrznych już podczas I wojny światowej, w ramach tworzonego przez okupantów niemieckiego i austriacko-węgierskiego Królestwa Polskiego. Nastąpiło to na mocy dekretu Rady Regencyjnej z 3 stycznia 1918 r. „O tymczasowej orga-

1 W. Kozyra, Polityka administracyjna ministrów spraw wewnętrznych Rzeczypospolitej Polskiej w latach 1918-1939, Lublin 2009, s. 24.

${ }^{2}$ Ibidem, s. 232-233. 
nizacji władz naczelnych w Królestwie Polskim"3. Bardzo szybko jednak, gdyż już 4 kwietnia 1918 r., sprawy te zostały przekazane ministrowi opieki społecznej i ochrony pracy (MOSiOP), którego w związku z tym przemianowano na ministra zdrowia publicznego, opieki społecznej i ochrony pracy (MZPOPiOP). Stan ten trwał do 30 października 1918 r., kiedy to następnym dekretem Rady Regencyjnej resort MZPOPiOP podzielono na: Ministerstwo Pracy i Opieki Społecznej (MPiOP) oraz Ministerstwo Zdrowia Publicznego (MZP) ${ }^{4}$. Z chwilą odzyskania przez Polskę niepodległości, 11 listopada 1918 r., sprawy zdrowia publicznego znalazły się więc poza strukturami resortu spraw wewnętrznych (administracji spraw wewnętrznych), skupione w samodzielnym resorcie zdrowia publicznego. Dość szybko jednak z powodu oszczędności budżetowych resort ten ustawą z dnia 28 listopada 1923 r. został zlikwidowany ${ }^{5}$, a rozporządzenie Prezydenta RP z 18 stycznia 1924 r. zasadniczą część jego kompetencji przekazywało ponownie urzędowi ministra spraw wewnętrznych. W związku z tym w Ministerstwie Spraw Wewnętrznych (MSW) na mocy rozporządzenia Rady Ministrów z 3 marca 1924 r. został utworzony nowy departament pod nazwą: Generalna Dyrekcja Służby Zdrowia (GDSZ) $)^{6}$. Odtąd funkcje kompetentnej władzy centralnej w dziedzinie ochrony zdrowia publicznego pełnili szefowie administracji spraw wewnętrznych. Podstawą prawną ich działania była przede wszystkim ustawa sanitarna z 19 lipca 1919 r. obowiązująca w byłym zaborze rosyjskim i austriackim, a ponadto przepisy prawa pruskiego (b. zabór pruski) i ustawodawstwo zdrowotno-sanitarne województwa śląskiego ${ }^{7}$. Na mocy tego ustawodawstwa do ministra spraw wewnętrznych należał zwierzchni nadzór na wszelkimi zagadnieniami zdrowotnymi w państwie, ogólne kierownictwo nad sprawami lekarskimi oraz prowadzenie działów zajmujących się kwestiami zdrowotnymi i higieną społeczną z wyjątkiem tych, które ustawowo zostały przekazane kompetencji innych resortów ${ }^{8}$.

3 Dziennik Praw Państwa Polskiego [dalej: DzPrPP], 1918, nr 1, poz. 1.

${ }^{4}$ DzPrPP, 1918, nr 1, poz. 1; nr 5, poz. 8; nr 14, poz. 31; K.W. Kumaniecki, Ustrój państwowych władz administracyjnych na ziemiach Polski, Kraków 1920, s. 22.

${ }^{5}$ Dziennik Ustaw Rzeczypospolitej Polskiej [dalej: DzURP], 1923, nr 131, poz. 1060.

${ }^{6}$ DzURP, 1924, nr 9, poz. 86; E. Więckowska, Walka z ostrymi chorobami zakaźnymi w Polsce w latach 1918-1924, Wrocław 1999, s. 28-42.

${ }^{7}$ DzPrPP, 1919, nr 63, poz. 371; DzURP, 1920, nr 73, poz. 497; 1921, nr 100, poz. 720.

${ }^{8}$ Innymi resortami były: pracy i opieki społecznej (m in. lekarska opieka nad dzieckiem i macierzyństwem, nad inwalidami i kalekami, higiena pracy w przemyśle, górnictwie i rzemiosłach), wyznań religijnych i oświecenia publicznego (higiena szkolna), spraw wojskowych (wojskowe sprawy sanitarne), sprawiedliwości (higiena więzień), rolnictwa (sprawy weterynaryjne). Zob. K. Kumaniecki, B. Wasiutyński, J. Panejko, Polskie prawo administracyjne, cz. I-II, Kraków 1929, s. 303-304. 
Administrację zdrowia publicznego tworzyli: minister spraw wewnętrznych oraz podległa mu administracja ogólna, to jest wojewodowie, którym w urzędach wojewódzkich podlegały wydziały zdrowia publicznego, oraz starostowie, którzy nadzorowali lekarzy powiatowych. Oprócz nich funkcjonowały różnego rodzaju organy specjalne i rady. Były to: powstały 14 lipca 1920 r. urząd nadzwyczajnego komisarza do walki z epidemiami (NKWE), podporządkowany ministrowi spraw wewnętrznych 18 stycznia 1924 r. (odtąd każdy minister spraw wewnętrznych obligatoryjnie otrzymywał stanowisko NKWE9 ), Państwowy Zakład Badania Żywności i Przedmiotów Użytku, Państwowy Zakład Epidemiologiczny (7 września 1923 r. przekształcony w Państwowy Zakład Higieny), Państwowy Zakład Badania Surowic, Państwowy Instytut Farmaceutyczny, Państwowa Szkoła Higieny ${ }^{10}$, Państwowa Rada do Spraw Uzdrowisk, Komisja Farmacji Polskiej, Państwowa Rada Zdrowia, Rada Spożywców, Państwowa Komisja dla Badania Pochodnych Arsenobenzolu oraz Polski Komitet Zwalczania Gruźlicy ${ }^{11}$.

W latach 1924-1926 polityka administracyjna kierownictwa resortu spraw wewnętrznych w zakresie zdrowia publicznego była realizowana przede wszystkim przez struktury administracji ogólnej. Dlatego bardzo ważnymi informacjami o stanie zdrowotności publicznej w poszczególnych regionach kraju były raporty i sprawozdania przesyłane do MSW przez urzędy wojewódzkie. Przykładowo, sprawozdanie wojewody łódzkiego za wrzesień 1925 r. przedstawiało informacje o stanie zdrowia we wszystkich powiatach oraz miastach wydzielonych województwa. Jeśli chodzi o Łódź, to sprawozdanie oddziału sanitarnego magistratu m. Łodzi, informowało o: posiedzeniach lekarzy sanitarnych, oględzinach sanitarnych, stanie zdrowotnym miasta oraz walce z chorobami zakaźnymi. W części dotyczącej stanu zdrowotnego miasta podawało, że na choroby „ostro zakaźne” zapadło: dur plamisty - 0 osób (w sierpniu - 0); dur brzuszny - odpowiednio: 159 (80); czerwonka - 7 (4), płonica - 76 (54). Łącznie na 15 rodzajów tych chorób zapadło 357 (235) osób. Zgonów w tym czasie było zaś 142 (156). Z zestawienia wynikało, że prawie dwukrotnie wzrosła liczba zachorowań na tyfus plamisty w porównaniu z miesiącem poprzednim. Tłumaczono, że zjawisko to powtarzało się co roku we wrześniu, nie wyjaśniając jednak, dlaczego tak się działo. Zwiększyła się też zachorowalność na błonicę i płonicę, natomiast na inne

9 DzURP, 1920, nr 61, poz. 388; R. Hausner, Pierwsze dwudziestolecie administracji spraw wewnętrznych, Warszawa 1939, s. 55; E. Więckowska, Walka z ostrymi chorobami zakaźnymi..., s. $51-61$.

${ }^{10}$ DzURP, 1923, nr 71; poz. 420; Monitor Polski [dalej: M.P.], nr 66, rozporządzenie RM z 14.03.1919; nr 258, rozporządzenie RM z 6.10.1921; nr 208, rozporządzenie RM z 7.09.1923; nr 1, ex 1922, rozporządzenie z 1.12.1921; nr 101, rozporządzenie RM z 13.04.1922; nr 147, rozporządzenie RM z 19.06.1922.

${ }^{11}$ DzURP, 1922, nr 31, poz. 254; 1920, nr 84, poz. 561; M.P. 1922, nr 142, nr 289, nr 148. 
choroby zakaźne - uległa zmniejszeniu. W podsumowaniu stwierdzono, że stan zdrowotności $\mathrm{w}$ mieście uległ pogorszeniu we wrześniu, w porównaniu z sierpniem 1925 r., choć nie osiągnął tak złego poziomu, jaki był w tym samym czasie w 1923 i 1924 r. $^{12}$

Szefowie MSW wraz z podległymi im służbami terenowymi dokonywali ciągłych kontroli stanu sanitarnego poszczególnych gmin wiejskich, miast i powiatów. Minister spraw wewnętrznych Zygmunt Hübner po inspekcji miasta Krakowa pisał 30 lipca 1924 r. do wojewody krakowskiego, że stan sanitarny miasta pozostawiał wiele do życzenia. Ulice nie były oczyszczane w dostateczny sposób, śmieci zalegały dłuższy czas na podwórzach. Minister domagał się sprawozdania z prac dokonanych przez odpowiednie służby i władze sanitarne. W odpowiedzi wojewoda krakowski nakazał przeprowadzenie gruntownej inspekcji sanitarnej m. Krakowa, która częściowo potwierdziła zarzuty ministra. W konsekwencji 20 września 1924 r. wydał on okólnik dotyczący usuwania nieczystości z Krakowa, jak i miast województwa krakowskiego. Odtąd starostowie mieli „z całą energią” wpływać na zarządy gminne miast i miasteczek, aby uregulowały sprawę oczyszczania „dołów kloaczych i śmietników” w ten sposób, że albo same zajmą się ich oczyszczaniem na koszt właścicieli realności, albo czynności te poruczą odpowiedzialnemu przed urzędem gminy przedsiębiorcy. Oczyszczanie tych miejsc powinno odbywać się regularnie i nie należało dopuszczać do przepełniania się zbiorników. W każdym mieście należało wyznaczyć odpowiednie miejsce, położone z dala od domów i wód publicznych, przeznaczone na składanie nieczystości i śmieci ${ }^{13}$.

Wojewoda stanisławowski Edmund Jurystowski pismem z dnia 20 października 1924 r. przesyłał natomiast do MSW wyjaśnienia poinspekcyjne starostów kałuskiego i stryjskiego w sprawie „,wadliwości sanitarnych” w mieście Kałusz i Stryj. Pisano tam, że miasto Kałusz w czasie wojny zostało zniszczone głównie w śródmieściu i „odbudowuje się leniwo”. W rynku znajdowało się w ruinie kilka domów murowanych, których właściciele nie byli w stanie odbudować lub przebywali poza granicami kraju. Podczas jarmarków domy te służyły za miejsca ustępowe, a okoliczni mieszkańcy z ,upodobaniem wyrzucają tam śmieci i odpadki domowe”. Na podwórzach innych domów, szczególnie w części miasta zamieszkałej przez ludność żydowską, ,znajdują się kupy śmieci, które ani właściciel realności, ani lokatorzy w sporach często ze sobą pozostający nie czują się zobowiązani usuwać". Starosta przytaczał w swym piśmie jeszcze wiele innych przykładów fatalnego stanu sanitarnego miasta. Poza tym opisem nie przedstawił

${ }^{12}$ Archiwum Akt Nowych, Ministerstwo Opieki Społecznej, Departament Służby Zdrowia [dalej: AAN, MOS, DSZ], sygn. 767, k. 85-95, pismo wojewody łódzkiego z 10.11.1925.

${ }_{13}$ Archiwum Państwowe w Katowicach, Urząd Wojewódzki Śląski, Wydział Prezydialny [dalej: APKat, UWŚ, WP], sygn. 1, k. 58; AAN, MOS, DSZ, sygn. 767, k. 126. 
jednak żadnych propozycji zmian ani swoich zarządzeń w tym zakresie. Wydaje się, że władze administracyjne biernie przyglądały się tej sytuacji, nie widząc żadnej możliwości zmiany na lepsze ${ }^{14}$.

Pod egidą ministrów spraw wewnętrznych organizowane były tzw. kolumny epidemiczne (epidemiologiczne), które miały na celu zwalczanie wybuchających epidemii, a zwłaszcza zapobieganie im. W 1924 r. wydali „Instrukcję dla kolumn epidemicznych", przeznaczonych do walki z durem plamistym i powrotnym. Kolumna składała się z lekarza jako jej kierownika, higienistki i dezynfektora. Wyposażona była w materiał sanitarny i propagandowy. Kierownik kolumny prowadził książkę (dziennik) czynności, gdzie notował wszystkie dokonane w danym dniu czynności, a pod koniec miesiąca składał raport swojemu przełożonemu. Do instrukcji dołączona była informacja o sposobach pobierania i przesyłania materiałów do badań laboratoryjnych ${ }^{15}$.

Wśród chorób zakaźnych najgroźniejszą chorobą społeczną była gruźlica. Dziesiątkowała ona głównie młodzież oraz ludność z warstw uboższych. Dlatego Generalna Dyrekcja Służby Zdrowia MSW postanowiła opracować „Państwowy program walki z gruźlicą". Jego zarys został przygotowany już w połowie $1924 \mathrm{r}$. Pisano w nim, że w pierwszej kolejności należy podnieść stan higieniczno-sanitarny urzędów państwowych. Powinny być one wzorem czystości i zdrowotności dla innych instytucji społecznych i prywatnych. W urzędach publicznych pracowało i przebywało (jako interesanci) setki tysięcy osób narażonych na zarażenie gruźlicą. Dotyczyło to także szkół „w których panuje przeludnienie i związane z nim zapadanie na gruźlicę". Zalecano, by do budżetu resortu spraw wewnętrznych na rok 1925 wstawić sumę 250 tys. zł „na doprowadzenie urzędów pod kontrolą właściwego lekarza powiatowego do należytego stanu sanitarnego". Zamierzano zorganizować system skutecznej izolacji chorych „na gruźlicę rozpadową”. Chorych należało za wszelką cenę odizolować od ich środowiska, a zwłaszcza od rodziny, którą zarażali. W szpitalach powinny powstać specjalne oddziały „gruźlicy otwartej”. Planowano zakładanie przychodni przeciwgruźliczych i tworzenie w ich ramach wywiadowni przeciwgruźliczych. Popierano rozwój sanatoriów i przychodni społecznych poprzez udzielanie im zapomóg finansowych. Na szeroką skalę prowadzono propagandę przeciwgruźliczą ${ }^{16}$. W $1925 \mathrm{r}$. minister spraw wewnętrznych pisał do wojewodów, że GDSZ MSW wraz ze Związkiem Przeciwgruźliczym przystąpiły

${ }^{14}$ AAN, MOS, DSZ, sygn. 767, k. 223-225.

15 Archiwum Akt Nowych, Ministerstwo Opieki Społecznej, Departament Opieki Społecznej, sygn. 5, s. 7; M.P. 1924, nr 203, akcja Generalnej Dyrekcji Służby Zdrowia w sprawie zwalczania kiły wśród Hucułów.

16 AAN, MOS, DSZ, sygn. 769, s. 300-303, pismo MSW z 30.06.1924. M. Olszewska, Kwestie zdrowotne w szkolnictwie II Rzeczypospolitej [w:] J. Nosko (red.), Z dziejów zdrowia publicznego, Łódź 2007, s. 233-253. 
do opracowania ,ankiety w sprawie środków społecznych walki z gruźlicą”. Rozesłano ją do Kas Chorych, szpitali, do wszystkich instytucji prowadzących walkę z gruźlicą, urzędów administracji rządowej i organów samorządu terytorialnego. Po jej opracowaniu miał się ukazać informator zatytułowany „Polski Arsenał Przeciwgruźliczy" jako niezbędny materiał informacyjny dla lekarzy i tych wszystkich, którzy zajmowali się walką z gruźlicą. Zestawienie w nim z jednej strony ognisk choroby (statystyka), z drugiej zaś - istniejących środków obrony miało pozwolić na racjonalną walkę $\mathrm{z}$ tą plagą społeczną. $\mathrm{W}$ następnej ankiecie, skierowanej przez MSW tylko do władz administracyjnych, domagano się informacji o liczbie towarzystw przeciwgruźliczych działających w poszczególnych województwach oraz szczegółowego wykazu zakładów leczniczych (przychodni przeciwgruźliczych, sanatoriów, szpitali, przytułków, zakładów „dla dzieci zołzowatych”, kolonii i półkolonii letnich). W odpowiedzi urzędy wojewódzkie informowały kierownictwo resortu o formach i sposobach walki z tą chorobą na podległym im terenie. Wojewoda tarnopolski raportował, że w jego okręgu nie prowadzono akcji przeciwgruźliczej, a społeczeństwo pod tym względem nie było uświadomione. Dopiero niedawno zaczęto organizować koła walki z gruźlicą w oparciu o Kasy Chorych. Natomiast na początku 1926 r. Urząd Wojewódzki Wileński pisał, że w jego okręgu walka z tą chorobą była prowadzona przez szereg instytucji państwowych, samorządowych i społecznych. Były to: Towarzystwo Przeciwgruźlicze w Wilnie, wileńska Kasa Chorych, magistrat m. Wilna, Dyrekcja Kolei Państwowych, stowarzyszenie żydowskie „Miszmeres Chojlim”, Lecznica Litewskiego Stowarzyszenia Pomocy Sanitarnej, sejmik powiatowy święciański, wileńsko-trocki, brasławski, oszmiański itd. W ankiecie z Przychodni-Poradni Wileńskiego Towarzystwa Przeciwgruźliczego informowano, że jej budżet na rok 1926 wynosił 20 605,92 zł. Zatrudnionych w niej było dwóch lekarzy, cztery siostry (pielęgniarki), kierownik biura i woźny ${ }^{17}$.

Kierownictwo GDSZ MSW nadzorowało funkcjonowanie aptek i składów farmaceutycznych. Przykładowo, w województwie lubelskim w pierwszej połowie lat 20. było ogółem 149 aptek, w tym publicznych 142, jedna kolejowa, jedna szpitalna i cztery przy Kasach Chorych. W tej liczbie mieściło się 80 składów aptecznych i trzy hurtownie leków. Jedna apteka przypadała na 14,6 tys. mieszkańców, co lokowało to województwo na 8.-9. miejscu w kraju. Inspektorzy farmaceutyczni Lubelskiego Urzędu Wojewódzkiego przeprowadzali dość częste kontrole aptek, wykrywając znaczne nieprawidłowości w ich funkcjonowaniu. Dlatego zalecali ich kierownikom ściślejszą współpracę z Państwowym Zakładem Higieny w Warszawie ${ }^{18}$.

${ }^{17}$ AAN, MOS, DSZ, sygn. 1422, k. 4, pismo MSW z 8.10.1925.

${ }_{18}$ Archiwum Państwowe w Lublinie, Urząd Wojewódzki Lubelski, Wydział Ogólny [dalej: APL, UWL, WO], sygn. 269, s. 30-31; W. Kozyra, Urząd Wojewódzki w Lublinie w latach 1919- 
Ministrowie spraw wewnętrznych w swojej polityce administracyjnej przywiązywali dużą wagę do szkolenia personelu administracyjnego i medycznego pracującego w publicznej służbie zdrowia. W Państwowej Szkole Higieny organizowano cykliczne kursy doszkalające dla lekarzy powiatowych, inspektorów pracy, pracowników wydziałów zdrowia urzędów wojewódzkich itp. Dość często poszczególne kursy otwierali ministrowie spraw wewnętrznych lub dyrektorzy GDSZ. W 1925 r. ustalono wykaz stanowisk oraz dokonano stabilizacji zawodowej urzędników państwowej służby zdrowia ${ }^{19}$.

2. W dniu 12 maja 1926 r. marszałek Józef Piłsudski dokonał zamachu stanu wobec konstytucyjnego rządu Wincentego Witosa. Władzę w Polsce na długie lata przejął obóz polityczny skupiony wokół J. Piłsudskiego, nazywany piłsudczykowskim bądź sanacyjnym. Zaraz po zamachu majowym nowe kierownictwo Ministerstwa Spraw Wewnętrznych przystąiło do realizowania nowej polityki administracyjnej resortu spraw wewnętrznych. Piłsudczycy inaczej widzieli jego rolę i znaczenie w państwie, inaczej też postrzegali formy i metody jego oddziaływania na społeczeństwo. Uznawali, że problem bezpieczeństwa publicznego należy sprowadzić „,o właściwej miary", wskazując, że głównym przedmiotem polityki administracyjnej resortu spraw wewnętrznych powinny być ,zagadnienia ogólnopolityczne”. Przez ich pryzmat należało rozważać wszystkie kwestie wchodzące w zakres uprawnień urzędu ministra spraw wewnętrznych, w tym te dotyczące bezpieczeństwa i porządku publicznego. Szefowie administracji spraw wewnętrznych skupiali się odtąd na dokładnym rozpoznaniu życia społeczno-politycznego w państwie oraz na jego dogłębnej analizie ${ }^{20}$.

Lata 1926-1930 to pierwszy okres realizacji piłsudczykowskiej koncepcji polityki administracyjnej w zakresie zdrowia publicznego. Już 1 lipca $1926 \mathrm{r}$. wraz z wejściem w życie nowego statutu organizacyjnego Ministerstwa Spraw Wewnętrznych Generalna Dyrekcja Zdrowia przekształcona została w Departament Służby Zdrowia. W ten sposób kierownictwo resortu zamierzało bardziej zintegrować dział służby zdrowia z pozostałymi pionami administracji spraw wewnętrznych. Rola tego działu znacznie wzrosła, gdy ministrem spraw wewnętrznych został gen. Sławoj F. Składkowski, lekarz i doktor medycyny. Rozwinął on autorski program wzmocnienia zdrowotności publicznej przez podniesienie ogól-

1939, Lublin 1999, s. 216. Por. E. Więckowska, Państwowy Zakład Higieny w Polsce w latach 1918-1954. Organizacja, cele, zadania, „Medycyna Nowożytna” 2001, t. 8, z. 2.

${ }_{19}$ Archiwum Akt Nowych, Prezydium Rady Ministrów, Rektyfikaty, nr 1, t. 7, pismo MSW z 16.07.1925; Archiwum Akt Nowych, Ministerstwo Spraw Wewnętrznych, Dopływy z b. Centralnego Archiwum Ministerstwa Spraw Wewnętrznych i b. Centralnego Archiwum Komitetu Centralnego Polskiej Zjednoczonej Partii Robotniczej [dalej: AAN, MSW, Dop.], sygn. 1002, k. 21; M.P. 1925, nr 21, wizyta ministra spraw wewnętrznych C. Ratajskiego w Państwowej Szkole Higieny - zakończenie kursu inspektorów pracy.

${ }^{20}$ W. Kozyra, Polityka administracyjna..., s. 335-336. 
nego stanu sanitarnego kraju, higieny społecznej oraz kultury życia codziennego. S.F. Składkowski we wspomnieniach pisał:

Jako minister spraw wewnętrznych zostałem mianowany jednocześnie nadzwyczajnym komisarzem do walki z epidemiami. Postanowiłem dołożyć wszelkich starań, by prowadzić dalej rozpoczęte dzieło [swego poprzednika - W.K.] profesora Emila Godlewskiego. Prócz mego profesora przyświecała mi jako wzór do naśladowania postać prefekta Sekwany Poubelle. Gdy jednak Poubelle użerać się musiał o czystość z niecałym milionem współczesnych paryżan, ja wymachując higienicznym tomahowkiem, rzuciłem się $\mathrm{w}$ walkę dosłownie $\mathrm{z}$ trzydziestu pięciu milionami mieszkańców Polski [...]. Pierwszym wrażeniem ludności było bezbrzeżne osłupienie, że „władza” zajmuje się „takimi rzeczami”. - Dajcie społeczeństwu dobrobyt, a już ono samo, bez żadnych nakazów, da sobie radę z higieną! - wołali zwolennicy złotej wolności.

Wskazując na dzieje Francji, wyjaśniał:

Dobrobyt nie zawsze idzie $\mathrm{w}$ parze $\mathrm{z}$ higieną. Trudno czekać, aż ten dobrobyt nadejdzie, gdyż na przykład dzisiaj [lata 50. XX w. - W.K.] już przy pojedynczym wypadku czerwonki lub tyfusu we wsi można klozet zdezynfekować, a nie zrobimy tego z zastodolem, roznoszącym zarazę z wodą deszczową i wiatrem. Do stworzenia warunków zdrowotnych społeczeństwa trzeba uświadomienia, wskazań, pouczeń i nakazów. A przede wszystkim same władze uświadomione być muszą co do swych obowiązków wobec zdrowia ludności ${ }^{21}$.

Kierownictwo resortu spraw wewnętrznych po półtorarocznym okresie (od marca 1927 r. do września 1928 r.) prowadzenia akcji „Podniesienie zdrowotności i wyglądu kraju" w okólniku nr 173 z 25 września 1928 r. podsumowywało jej efekty oraz zakreślało plan działań na okres następny. Pisało, że zauważalna już była ogólna poprawa stanu sanitarnego miast, ogólne wzmocnienie stanu zadrzewienia (szczególnie przy drogach i szosach) i podniesienie wyglądu urzędów państwowych. W tym czasie $80 \%$ domów w miastach i $60 \%$ na wsiach zaopatrzonych było w ustępy, a $60 \%$ domów w miastach posiadało nakryte śmietniki.

Cyfry te, aczkolwiek jeszcze niedostateczne, wskazują jednak na to, że antysanitarna bierność ludności została przełamana i pod tym względem pierwszy etap rozpoczętej kampanii został pomyślnie zakończony ${ }^{22}$.

${ }^{21}$ S.F. Składkowski, Nie ostatnie słowo oskarżonego. Wspomnienia i artykuły, wstęp i opracowanie A. Adamczyk, Warszawa 2003, s. 23-24.

${ }^{22}$ AAN, MSW, Dop., sygn. 982, k. 96, okólnik MSW nr 173 z 25.09.1928; AAN, MOS, DSZ, sygn. 765, k. 143 - w okresie od października 1927 r. do marca 1928 r. w skali kraju: odnowiono 11479 domów w miastach, zbudowano 34218 nakrytych śmietników w miastach, zbudowano 68750 ustępów w miastach i 442172 na wsiach. Por. Z. Rudolf, Podstawowe zagadnienia zdrowotne wsi i miasteczek, Warszawa 1927, s. 5 i nn. 
Dalsze etapy tej akcji miały polegać nie tylko na utrzymaniu i umocnieniu rzeczy dokonanych i zdobytych, ale także na stopniowym opanowaniu i zdobywaniu nowych wartości. Minister spraw wewnętrznych rzucił hasło: „Wyjście z pracą na wieś!". Domagał się od wojewodów nie tylko popularyzowania tego hasła wśród podległej im administracji, ale także ,pedagogicznego, konsekwentnego i nieustępliwego wcielania tego hasła w życie”. Zapowiadał, że będzie żądał, „by wygląd wsi wymykającej się dotąd spod wpływów władzy uległ stanowczej i widocznej zmianie ku lepszemu". Zalecał, by na wsiach administracja rządowa i samorząd prowadziły propagandę mającą na celu przyzwyczajenie ludności do stałego korzystania $\mathrm{z}$ ustępów, a w miastach do budowy ustępów publicznych i zbiorowych. „Za wszelką cenę doprowadzić do tego, by w każdej szkole był ustęp i aby ustęp ten był higienicznie urządzony i utrzymany". Zarządził usuwanie brudów z podwórzy w miastach i wsiach. Miały być one stale czyszczone i zamiatane, a nawóz składany tylko w gnojowiskach, oddzielonych od reszty podwórza; studnie powinny być nakryte. Wygląd urzędów państwowych, zwłaszcza starostw, komend lub posterunków policji, szkół, dworców kolejowych „musi stać się wzorem czystości i porządku, ponadto winien on być możliwie estetycznym".

Należało wzmóc akcję zadrzewiania dróg, miast i wsi, przy uwzględnieniu wskazówek pisma okólnego MSW z 10 grudnia 1927 r. Trzeba było też wywrzeć odpowiedni wpływ na wydziały powiatowe, jako władze nadzorcze nad gminami wiejskimi i miejskimi, by te w swoich budżetach, przeznaczając odpowiednie sumy na budowę i utrzymanie dróg publicznych, zawsze przewidywały kredyty „na zadrzewianie” (drzewa, krzewy, rośliny pnące itp.). Administracja ogólna powinna pilnować, by rynki, domy kąpielowe, hotele i restauracje utrzymywane były o ile to możliwe we wzorowej czystości. Place targowe i rynki winny być wybrukowane, a w miastach wojewódzkich i liczących ponad 50 tys. mieszkańców drogi powinny mieć nawierzchnię asfaltową lub betonową. Budki i stragany do sprzedaży na placach targowych i rynkach musiały mieć estetyczny wygląd i być pomalowane. Należało doprowadzić do tego, by wszystkie domy mieszkalne w kraju (w miastach i na wsiach) były od ulicy i od podwórza otynkowane względnie pomalowane lub bielone, przy czym tynkowanie i bielenie miało być powtarzane w miarę zabrudzenia ścian, nie rzadziej jednak niż raz do roku. Wszystkie ogrodzenia w miastach powinny być pomalowane lub otynkowane. $\mathrm{Na}$ wsiach należało propagować ogrodzenia, przynajmniej od ulicy, w formie żywopłotów. Stanowczo zabraniano natomiast okładania domów słomą. Szef resortu domagał się też, by „oddymić i oczyścić ośrodki przemysłowe”. Doprowadzić do tego, by wszystkie budynki fabryk i zakładów przemysłowych były otynkowane lub pomalowane na kolor cegły, dziedzińce fabryczne nie tylko utrzymane schludnie, ale i upiększone roślinami pnącymi, krzewami, zieleńcami. Wszelkie 
ruiny niemające charakteru zabytkowego oraz rumowiska powinny być „usunięte z powierzchni kraju"23.

Według tego programu wojewodowie przygotowali „wojewódzkie plany działania na rzecz podniesienia zdrowotności kraju i jego wyglądu". Wojewoda wileński zarządził w marcu 1929 r., by podległe mu władze administracyjne i samorządowe poinformowały społeczeństwo o nim poprzez obwieszczenia publiczne. W ramach programu już od marca poczęto prowadzić szczegółową rejestrację stanu wszystkich domów mieszkalnych, ustępów, studni, gnojowisk, ulic, ogrodzeń oraz sprawdzać książki sanitarno-porządkowe dla poszczególnych posesji. W kwietniu i maju powinny być przeprowadzone prace porządkowe: malowanie (bielenie) domów mieszkalnych, grodzenie, zadrzewianie, porządkowanie ulic i podwórzy, oczyszczanie domów itp. Natomiast w drugiej połowie września i w październiku miała być prowadzona kontrola dokonanych prac na podstawie odpowiednich kart rejestracyjnych. Oporni, którzy nie zastosowali się do zaleceń, mieli być zaś pociągani do odpowiedzialności karnejej. W akcję tę angażowały się organizacje gospodarcze, społeczne i młodzieżowe. Jedną z nich był Centralny Związek Kółek Rolniczych, który w ramach kół gospodyń wiejskich prowadził różnego rodzaju kursy dotyczące gospodarstwa wiejskiego. Jego władze doszły jednak do wniosku, że należy najpierw przeprowadzić kursy na temat zdrowia publicznego i higieny społecznej. Brak takiej wiedzy wśród ludności wiejskiej rzutował bowiem na słabe wyniki w szkoleniach $\mathrm{z}$ gospodarstwa domowego. Stwierdzano, iż ,niejednokrotnie spotyka się, że młodzież biorąca udział w konkursach lepiej utrzymuje kurniki i chlewy niż własne mieszkania"25.

Z polityką administracyjną ministra S.F. Składkowskiego w zakresie „podniesienia zdrowotności i wyglądu kraju" korespondowała działalność prawodawcza Prezydenta Rzeczypospolitej, który wydał następujące rozporządzenia z mocą ustawy: 22 kwietnia 1927 r. o rozbudowie miast, 16 lutego 1928 r. o prawie budowlanym i o zaopatrywaniu ludności w wodę, 16 marca 1928 r. o usuwaniu nieczystości i wód opadowych ${ }^{26}$. W dniu 2 maja 1929 r. w Departamencie Służby Zdrowia MSW utworzono referat inżynierii sanitarnej, który koncentrował się na

${ }^{23}$ AAN, MSW, Dop., sygn. 982, k. 97, okólnik MSW nr 173 z 25.09.1928; APKat, UWŚ, WP, sygn. 1, k. 209, pismo MSW z 2.11.1927 w sprawie zadrzewiania miast, miasteczek, wsi. Por. M. Posłuszna, Stan sanitarno-higieniczny wsi polskiej w okresie II Rzeczypospolitej [w:] J. Nosko (red.), $Z$ dziejów zdrowia..., s. 284-287.

${ }^{24}$ Liteuvos Centrinis Valstyges Archyvas, Urząd Wojewódzki Wileński, Wydział Bezpieczeństwa, f. 51, ap. 17, b. 42, ark. 96; AAN, MOS, DSZ, sygn. 837, k. 66, 90.

${ }_{25}$ AAN, MOS, DSZ, sygn. 770, pismo Centralnego Związku Kółek Rolniczych - Centralnego Związku Młodzieży Wiejskiej „Siew” z 6.12.1928; sygn. 597, pismo CZKR - CZMW „Siew” z 28.11.1928.

${ }^{26}$ DzURP 1927, nr 42, poz. 372; nr 106, poz. 913; 1928, nr 23 poz. 202; nr 321, poz. 310 i 311; Archiwum Akt Nowych, Ministerstwo Spraw Wewnętrznych, Gabinet Ministra Wydział Prawno- 
przygotowywaniu dalszych norm prawnych w zakresie techniczno-sanitarnym. W drugiej połowie 1929 r. przygotowano następujące projekty aktów prawnych: tymczasowe normy dla wody do picia, tymczasowe normy oczyszczania ścieków, projekt ustawy o Funduszu Wodnym, projekt rozporządzenia o ustępach, gnojowiskach, kompostarniach, zbiornikach na śmieci. Ponadto znowelizowano ustawę o obrocie szmatami, przygotowano okólnik w sprawie walki z durem brzusznym drogą kontroli jakości wody i odkażania studzien oraz okólnik o stanie sanitarno-porządkowym szkół. Wspólnie z Państwowym Zakładem Higieny ustalono nowe normy bakteriologicznego badania wody oraz projekt ochrony ludności przed zadymieniem ${ }^{27}$.

W ramach polityki administracyjnej ministrów spraw wewnętrznych w zakresie zdrowia publicznego z dużym powodzeniem zwalczano choroby zakaźne, czego efektem był znaczny spadek zachorowalności na nie i zmniejszenie liczby zgonów. W 1928 r. ospa naturalna nie stanowiła już „zagadnienia pierwszej wagi ze względu na wprowadzoną sprężystą akcję przymusowych dorocznych szczepień". Podczas gdy w 1921 r. w związku z tą chorobą zanotowano 5078 zasłabnięć, w tym 823 zgony, w 1926 r. - 69 zasłabnięć, w tym 5 zgonów, to w 1928 r. było już tylko 21 zasłabnięć i 2 zgony. Podobne zmniejszenie dotyczyło: duru plamistego i powrotnego, duru brzusznego, czerwonki, płonicy, błonicy, odry, zakażenia połogowego, wodowstrętu, strupnia i liszaja strzygącego oraz zimnicy. Znaczne postępy poczyniono w walce $\mathrm{z}$ najtrudniejszą chorobą społeczną, jaką była gruźlica. Sukcesywnie powstawały pod nadzorem administracji ogólnej (zdrowia publicznego) sanatoria przeciwgruźlicze, głównie w miejscowościach uzdrowiskowych, oraz przychodnie przeciwgruźlicze. Walczono z postępem gruźlicy wśród dzieci i młodzieży. W tej sprawie wystąpiły kontrowersje między MSW a Ministerstwem Pracy i Opieki Społecznej co do skali ingerencji DSZ MSW w podległe MPiOS zakłady opieki nad matką i dzieckiem. Zwalczano alkoholizm i choroby weneryczne, a zwalczanie chorób zawodowych wysunęło się na ,jedno z czołowych miejsc w rzędzie zagadnień medycyny społecznej i ochrony pracy" 28 .

Administracja służby zdrowia dużo uwagi poświęciła stanowi szpitalnictwa krajowego. Na koniec grudnia 1927 r. wszystkich zakładów leczniczych w Polsce

\footnotetext{
-Organizacyjny [dalej: AAN, MSW, GMWPO], sygn. 471, projekt MSW o zmianie rozporządzenia Prezydenta RP o prawie budowlanym z 16.02.1928.

27 AAN, MSW, GMWPO, sygn. 8, sprawozdanie z działalności Referatu Inżynierii Sanitarnej: 1.07-31.12.1929; sygn. 707, k. 374-377.

${ }^{28}$ AAN, MSW, GMWPO, sygn. 707, k. 295-301, 332-333; 336-338, 340-356, 358-368; sygn. 1443, s. 30; Archiwum Państwowe w Lublinie, Urząd Wojewódzki Lubelski, Wydział Samorządowy, sygn. 28, s. 148-150; J. Sadowska, Lecznictwo ubezpieczeniowe w II Rzeczypospolitej, Łódź 1990, s. 158-162.
} 
było 672 z 58842 łóżkami. Natomiast pod koniec 1928 r. zakładów tych było 694 z 60658 łóżkami. Przybyły więc 22 szpitale i 1816 łóżek. Prowadzono nadzór farmaceutyczny nad aptekami i składami aptecznymi. W 1928 r. do Państwowego Zakładu Higieny przesłano 4261 próbek środków leczniczych pobranych przy rewizjach aptek i drogerii, a które nie mogły być zbadane podczas wizytacji. W 1930 r. Ministerstwo Spraw Wewnętrznych opracowało wzory formularzy dla wojewódzkich inspektorów farmaceutycznych, na podstawie których zakładali oni książki ewidencyjne dla poszczególnych aptek. Departament Służby Zdrowia przygotował generalną nowelizację ustawy o uzdrowiskach z 23 marca 1922 r., która weszła w życie jako rozporządzenie prezydenckie 22 marca $1928 \mathrm{r}$. Na jej podstawie za uzdrowiska uznano: a) miejscowości, w których znajdowały się cieplice lub zdroje lecznicze, czyli tzw. zdrojowiska; b) stacje klimatyczne; c) kąpieliska morskie. Uzdrowiska dzieliły się jeszcze na mające charakter użyteczności publicznej oraz niemające takiego charakteru ${ }^{29}$.

Ministrowie spraw wewnętrznych wiele wysiłku włożyli w odpowiednie przygotowanie fachowe pracowników administracji służby zdrowia. Zwracano uwagę na zjazdy lekarzy powiatowych i na jakość przygotowywanych przez nich referatów i sprawozdań. W latach 1926-1930 w Państwowej Szkole Higieny zorganizowano cztery kursy trachomatologii, dwa kursy dla higienistek i wywiadowczyń przeciwgruźliczych, dwa kursy dla lekarzy specjalizujących się w walce z jaglicą oraz dwa kursy dla położnych. Następnie cztery kursy alkohologii, w tym jeden trzymiesięczny, siedem kursów dla inżynierów sanitarnych i kontrolerów sanitarnych, w tym jeden czteromiesięczny, oraz dziewięciomiesięczny kurs higieny społecznej dla lekarzy powiatowych. Co roku odbywały się też kursy dla lekarzy - kandydatów do państwowej i samorządowej służby zdrowia, szkolenia dla lekarzy zajmujących się sprawami wychowania fizycznego, kursy dla higienistek - „wywiadowczyń wiejskich” oraz szereg wykładów dla „działaczek na polu zdrowia publicznego"30.

3. Lata $1930-1935$ to przede wszystkim czas Wielkiego Kryzysu Gospodarczego, z którym walczyło całe społeczeństwo, a władze państwowe na szeroką skalę prowadziły działania oszczędnościowe mające na celu przywrócenie

${ }^{29}$ AAN, MSW, GMWPO, sygn. 707, k. 364-365; k. 378-382; k. 384; Archiwum Państwowe w Katowicach, Urząd Wojewódzki Śląski, Wydział Zdrowia Publicznego [dalej: APKat., UWŚ, WZP], sygn. 2, pismo MSW z 19.11.1930; K.W. Kumaniecki, B. Wasiutyński, J. Panejko, Polskie prawo administracyjne, s. 322.

${ }^{30}$ Archiwum Państwowe w Krakowie, Dyrekcja Robót Publicznych w Krakowie, Wydział Ogólno-Administracyjny [dalej: APKr., DRPKr., WOA], sygn. 131 a, bp, pismo MSW z 16.07.1930; AAN, MOS, DSZ, sygn. 486, okólnik MSW z 10.02.1928; W. Kozyra, Polityka administracyjna..., s. 399. 
zachwianej równowagi budżetowej państwa. W ich wyniku nastąpiła znacząca redukcja korpusu urzędniczego oraz oszczędności organizacyjne w strukturach administracji publicznej, w tym w resorcie spraw wewnętrznych. $Z$ dniem 1 lipca 1932 r. z uprawnień ministra spraw wewnętrznych wyłączono sprawy zdrowia publicznego z wyjątkiem zagadnień sanitarno-technicznych i przekazano je ministrowi pracy i opieki społecznej (od 12 lipca 1932 r. ministrowi opieki społecznej). W dniu 25 czerwca 1932 r. wszedł w życie nowy statut organizacyjny Ministerstwa Spraw Wewnętrznych, który te zmiany usankcjonował ${ }^{31}$. W rzeczywistości kwestia wyłączenia spraw zdrowia publicznego spod kompetencji MSW trwała jeszcze przez jakiś czas, czego dowodem było pismo ministra spraw wewnętrznych Bronisława Pierackiego z listopada 1932 r., w którym prosił MOS, by wszelkie projekty rozporządzeń oparte na dawnych normach ustawowych, których wykonanie przed 1 lipca 1932 r. należało do MSW, były mu przesyłane do dalszego uzgadniania ${ }^{32}$.

W konsekwencji ministrowie spraw wewnętrznych swoją dotychczasową politykę administracyjną w zakresie zdrowia publicznego prowadzili tylko do 1 lipca 1932 r. W tym czasie Departament Służby Zdrowia MSW zwracał szczególną uwagę na organizację i funkcjonowanie administracji zdrowia publicznego, na system opieki zdrowotnej, zwalczanie chorób, w szczególności zakaźnych, oraz zagadnienia higieniczno-sanitarne. W dniach 3-4 lutego $1931 \mathrm{r}$. w MSW zorganizowany został zjazd naczelników wydziałów zdrowia publicznego urzędów wojewódzkich. Poruszono na nim takie kwestie, jak: zwalczanie ostrych chorób zakaźnych, w szczególności duru brzusznego, błonicy, płonicy, oraz stosowanie w walce z nimi najnowszych osiągnięć europejskiej bakteriologii i serologii; zwalczanie gruźlicy przez polską służbę zdrowia i rolę w tym dziele Polskiego Związku Przeciwgruźliczego, zwalczanie chorób wenerycznych i rolę w tym Polskiego Związku Przeciwwenerycznego. Podczas zjazdu omawiano też działalność ośrodków zdrowia, współdziałanie państwowych zakładów badania żywności i przedmiotów powszechnego użytku z państwową służbą zdrowia oraz pracę Działu Chemii w Państwowym Zakładzie Higieny ${ }^{33}$.

Dnia 14 października 1930 r. DSZ MSW wydał „Instrukcję dla inspekcji wojewódzkiej w dziale zdrowia publicznego". Organami tej inspekcji byli: naczelnik wydziału zdrowia, inspektor lekarski, inspektor farmaceutyczny. Do zakresu czynności naczelnika wydziału zdrowia należało: nadzorowanie pracy lekarzy powiatowych, samorządowych, okręgowych, rejonowych, gminnych. Kontrolowa-

${ }^{31}$ DzURP, 1932, nr 51, poz. 479; poz. 480; M.P. nr 148, uchwała RM z 25.06.1932.

32 AAN, MSW, GMWPO, sygn. 4, pismo MSW z listopada 1932 r. do MOS.

${ }^{33}$ AAN, MSW, GMWPO, sygn. 493, k. 361. Szerzej: E. Więckowska, Organizacja centralnych urzędów publicznej stużby zdrowia w II Rzeczypospolitej, „Zdrowie Publiczne” 1984, t. 95, z. 11. 
nie szkół w zakresie przestrzegania przepisów sanitarnych, lecznictwa w Kasach Chorych, medycznego personelu lekarskiego i pomocniczego (lekarze, dentyści, felczerzy, technicy dentystyczni, pielęgniarki, kontrolerzy sanitarni); kierowanie walką z chorobami społecznymi (gruźlica, jaglica, nierząd, choroby weneryczne, alkoholizm); czuwanie nad stanem higieny w szkołach, więzieniach, pomieszczeniach dworcowych oraz nad czystością powietrza, gleby, placów, ulic miejskich, zagród wiejskich itp. ${ }^{34}$

Wydział Zdrowia Urzędu Wojewódzkiego Lubelskiego informował, że w latach 1930-1931 na obszarze jego działania nasilającą się chorobą był dur brzuszny, co było charakterystyczne dla całego państwa. W 1930 r. na Lubelszczyźnie zachorowało na tę chorobę 806 osób, a w 1931 r. - 945 osób. Zachorowalność na pozostałe choroby zakaźne była następująca (odpowiednio): dur plamisty 209 (117), płonica - 1258 (962), błonica - 677 (603), odra - 1741 (600), czerwonka - 57 (47). Szczepień ochronnych na dur brzuszny wykonano w $1930 \mathrm{r}$. 8885 , a w 1931 r. $-5388^{35}$. Walkę z tymi chorobami prowadzily różnego rodzaju placówki służby zdrowia. W województwie lubelskim na początku 1932 r. funkcjonowało 39 szpitali publicznych z 2383 łóżkami i dwie prywatne lecznice z 20 łóżkami. Ogólnie rzecz ujmując, jedno łóżko przypadało na 1013 mieszkańców Lubelszczyzny. Wśród województw Polski centralnej było to ostatnie miejsce, gdyż np. w województwie kieleckim jedno łóżko przypadało na 990 mieszkańców, w warszawskim - na 741, w łódzkim - na 612, a w poznańskim - na 333. Sytuację pogarszał fakt, że tylko $62 \%$ szpitali miało zajętą więcej niż połowę łóżek, a 38\% z nich nie osiągnęło nawet tego stanu. W 25 szpitalach na 39 wykorzystywano więcej niż połowę „,ni szpitalnych” w ciągu roku. Placówki te znajdowały się w bardzo trudnej sytuacji finansowej. Żaden szpital nie utrzymywał się samodzielnie, a tylko dzięki różnego rodzaju dotacjom, głównie rządowym i samorządowym. Pacjenci jednak zwykle nie płacili za leczenie. Gdyby choć w połowie szpitale te otrzymały należne im sumy, ich sytuacja byłaby o wiele lepsza, ponieważ zaległości te wynosiły ponad $3 \mathrm{mln} \mathrm{z}^{36}$.

Wielkie znaczenie $\mathrm{w}$ zwalczaniu chorób zakaźnych miały różnego rodzaju organizacje społeczne. Wojewoda lwowski w sprawozdaniu z 1931 r. informował MSW o działalności Wojewódzkiego Towarzystwa Przeciwgruźliczego z siedzibą we Lwowie. Instytucja ta zorganizowała 28 marca 1931 r. I Wojewódzki Zjazd Przeciwgruźliczy. Koordynowała pracę powiatowych kół walki z gruźlicą, przychodni przeciwgruźliczych oraz powiatowych kas chorych.

${ }^{34}$ APKat., UWŚ, WZP, sygn. 1, k. 1.

${ }^{35}$ APL, UWL, WO, sygn. 720, s. 53.

${ }^{36}$ Ibidem, s. 53-54. Zob. J. Sadowska, Organizacja opieki zdrowotnej w systemie ubezpieczenia chorobowego na Wileńszczyźnie (1922-1933), „Archiwum Historii i Filozofii Medycyny” 1999, t. 62 , z. $1-2$. 
Stowarzyszenie działało na rzecz pomocy dla bezrobotnych gruźlików, wysyłając ich na leczenie do sanatorium w Hołosku. Podlegało mu 28 przychodni przeciwgruźliczych, w których pracowało 18 lekarzy, a brakowało ich jeszcze w 15 przychodniach ${ }^{37}$.

Administracja zdrowia publicznego, prowadząc walkę z chorobami zakaźnymi, propagowała wśród lekarzy eugenikę, to jest naukę „która zajmowała się wszelkimi czynnikami mającymi wpływ na polepszenie wrodzonych właściwości jakiejś rasy i rozwijanie jej w najpomyślniejszym kierunku" (F. Galton). Po I wojnie światowej zainteresowania eugeniki jako „nauki o hodowli człowieka” zmieniły się na rzecz zagadnień higieniczno-medycznych. Zaczęto ją częściej określać jako „naukę higieny rasy” (Niemcy). W latach 30. dzielono ją na eugenikę teoretyczną i praktyczną. Ministerstwo Spraw Wewnętrznych, propagując wiedzę na temat eugeniki wśród personelu medycznego, organizowało dla niego liczne kursy i szkolenia w Państwowej Szkole Higieny pod ogólną nazwą „kursów dla lekarzy z zakresu eugeniki i poradnictwa przedślubnego"38.

Ministrowie spraw wewnętrznych nadal nadzorowali działalność podległych im służb w zakresie higieny społecznej i techniki sanitarnej (podniesienia zdrowotności i wyglądu kraju). MSW opracowało projekt rozporządzenia o utrzymaniu czystości na drogach publicznych i w obejściach gmin wiejskich oraz rozporządzenie „O ustępach i śmietnikach”. Z inicjatywy referatu sanitarnego MSW przystąpiono do organizacji Polskiego Komitetu Techniki Sanitarnej i Higieny Miast

${ }^{37}$ AAN, MOS, DSZ, sygn. 630, s. 1-10.

38 Głównym przedmiotem zainteresowań eugeniki były „obciążenia dziedziczne jednostek oraz przyczyny ich powstania”. Występowały one jako „pewne wady czy braki organizmu, które w warunkach życia nie ochranianego przez kulturę predestynowały obarczoną nimi jednostkę do wyselekcjonowania biologicznego". Obciążenia te mogły występować w budowie i funkcjach wszystkich bodaj narządów i układów organizmu człowieka. Eugenikę interesowały w szczególności wady i zaburzenia psychiczne. Poza obciążeniami dziedzicznymi zajmowała się też chorobami, które miały wybitnie hamujący wpływ na funkcje i komórki rozrodcze człowieka. Były nimi gruźlica i choroby weneryczne. Potomstwo osób zarażonych, zwłaszcza chorobami wenerycznymi, wykazywało zazwyczaj ogólną degenerację w postaci obniżenia poziomu zdrowia, zahamowania rozwoju itp.; objawy te mogły ustąpić dopiero po kilku pokoleniach. Podobnie zgubny wpływ dysgeniczny (w przeciwieństwie do pojęcia wpływu dodatniego - eugenicznego) na rozwój człowieka i jego potomstwo wywierał alkoholizm oraz używanie wszelkiego rodzaju narkotyków. W praktyce zagadnienia chorób wenerycznych i alkoholizmu, jako najszybciej degenerujące człowieka, były najważniejszymi kwestiami w zainteresowaniach medycznych eugeników światowych, jak i polskich pierwszej połowy XX w. - Archiwum Akt Nowych, Ministerstwo Opieki Społecznej, Gabinet Ministra, sygn. 15, k. 107-111; DSZ, sygn. 1585, k. 1; M.P. 1931, nr 61, kurs eugeniki i poradnictwa przedślubnego w Państwowej Szkole Higieny; M. Musielak, D. Hędzelek, Pojęcie i kryteria „osób małowartościowych” w pogladach eugenistów polskich $i$ amerykańskich przed II wojna światowa [w:] J. Nosko (red.), Z dziejów zdrowia..., s. 329-352. Szerzej: M. Gawin, Rasa i nowoczesność. Historia polskiego ruchu eugenicznego (1880-1952), Warszawa 2003, s. 9 i nn. 
jako stowarzyszenia o charakterze społecznym ${ }^{39}$. Kierownictwo resortu spraw wewnętrznych nadzorowało pracę aptek i składów farmaceutycznych. Nadzór ten wykonywali inspektorzy ministerialni i wojewódzcy. Mieli prawo kontrolowania całego obrotu ,środkami leczniczymi i truciznami”. W szczególności inspektor wojewódzki miał możność dokonywania rewizji aptek, drogerii i detalicznego handlu truciznami, a także hurtowni środków leczniczych i odurzających, wytwórni preparatów bakteryjnych (z wyjątkiem weterynaryjnych), ,preparatów organoterapeutycznych" oraz fabryk wód mineralnych. Inspektor udzielał koncesji na prowadzenie aptek i hurtowy handel eterem (na terenach województw centralnych i wschodnich wydawał koncesje drogeryjne). Prowadził ewidencję plantacji roślin lekarskich oraz zbieranych przez ludność roślin „dziko rosnących"40.

Urząd ministra spraw wewnętrznych dużą wagę przywiązywał do szkolenia personelu medycznego zatrudnionego w publicznej służbie zdrowia. Organizowano szkolenia głównie w Państwowej Szkole Higieny. Oprócz wspomnianych już kursów z eugeniki realizowano też kursy z organizacji społecznej walki z gruźlicą, jaglicą i innymi chorobami zakaźnymi, szkolenia z zakresu higieny publicznej dla działaczek społecznych i nauczycielstwa szkół powszechnych. W marcu $1931 \mathrm{r}$. zorganizowano kolejny (V) kurs dokształcania sanitarnego dla inżynierów, który ukończyło 19 osób ${ }^{41}$.

Wraz z wejściem w życie nowego Statutu Organizacyjnego MSW w dniu 25 czerwca 1932 r. w ramach Departamentu Techniczno-Budowlanego MSW zaczął funkcjonować referat techniki sanitarnej, pozostały po dawnym Departamencie Służby Zdrowia MSW. W urzędach wojewódzkich sprawami techniki sanitarnej zajmowały się nowe komórki organizacyjne: wydziały komunikacyjno-budowlane, a w starostwach - referaty państwowej służby budowlanej ${ }^{42}$.

W latach 1932-1935 referat techniki sanitarnej opracował wzorcowy regulamin sanitarno-porządkowy dla miast. Opiniował rozporządzenie ministra spraw wewnętrznych o nadzorze nad mięsem i przetworami mięsnymi, a także o projektach kąpielisk w wielu gminach (Podhajce, Rudki-Tartak), o budowie wodociągu i kanalizacji w Wilnie i o studniach gminnych (Niewodna, Gołonóg, Wielkie Chełmno). Jego przedstawiciele brali udział w konferencji w sprawie planu regionalnego dla m.st. Warszawy. Kierownik referatu techniki sanitarnej wystąpił do wojewody łódzkiego w sprawie zbadania możliwości zużytkowania stawów

${ }^{39}$ Archiwum Akt Nowych, Ministerstwo Spraw Wewnętrznych, Gabinet Ministra - Sekretariat Ministra [dalej: AAN, MSW, GM - SM], sygn. 817, k. 1-3.

${ }^{40}$ APKat., UWŚ, WZP, sygn. 1, k. 3; APKr., DRPKr., WOA, sygn. 147 c, k. 1379.

${ }^{41}$ AAN, MSW, GM - SM, sygn. 817, k. 2a; W. Kozyra, Polityka administracyjna..., s. 484.

${ }^{42}$ DzURP, 1932, nr 51, poz. 479; AAN, MSW, GMWPO, sygn. 744, k. 56; sygn. 7, k. 209; APKr., DRPKr., WOA, sygn. 131 b, bp, pismo MRP w sprawie projektu organizacji państwowej technicznej służby wodnej. 
w Łagiewnikach na otwarte kąpielisko. Zwrócił się o pomoc do MSZ w sprawie uzyskania zagranicznych materiałów fachowych dotyczących walki z zadymieniem atmosfery. Inicjował dalsze prace nad ochroną rzek przed zanieczyszczeniem, ściśle współpracując z placówkami naukowymi w Warszawie, Krakowie i Bydgoszczy. Jego pracownicy kierowali akcją propagandową MSW na rzecz studni osiedlowych, współpracując w tym względzie ze Związkiem Straży Pożarnych. Nadzorowali także fabrykę samochodów „Ursus”, która przystąpiła do produkcji mechanicznego sprzętu oczyszczania ulic ${ }^{43}$.

4. W ostatnich latach przed II wojną światową (1935-1939) polityka administracyjna resortu spraw wewnętrznych dotyczyła już tylko wąskiego zakresu spraw zdrowotnych, czyli kwestii techniczno-sanitarnych kraju. Były to sprawy techniczno-sanitarne osiedli, mieszkań, gmachów państwowych, zaopatrzenia ludności w wodę (wodociągi, źródła, ujęcia wody itp.), nieczystości i wód opadowych (kanalizacje, ustępy, usuwanie śmieci itp.), ochrony rzek przed zanieczyszczeniem, czystości powietrza ${ }^{44}$.

Gdy doktor medycyny gen. S.F. Składkowski został w maju 1936 r. prezesem Rady Ministrów, a jednocześnie ministrem spraw wewnętrznych, referat techniki sanitarnej znalazł się pod jego przemożnym wpływem. Odtąd komórka ta wydawała zwiększoną liczbę zarządzeń i instrukcji urzędom gminnym w sprawach właściwego zaopatrzenia ludności w wodę do picia oraz szeroko rozumianych potrzeb gospodarczych. Domagała się, by istniejące na terenie gmin publiczne i prywatne urządzenia wodne odpowiadały obowiązującym przepisom, a woda spełniała określone warunki fizyczne, chemiczne i bakteriologiczne. Przypominała, że budowa i utrzymanie wodociągów do użytku publicznego stanowiło wyłączne prawo gmin, chociaż mogły one zezwolić na budowę i utrzymanie wodociągów innym podmiotom prawnym lub fizycznym ${ }^{45}$.

S.F. Składkowski podczas inspekcji zwracał uwagę na przestrzeganie przepisów higienicznych i techniczno-sanitarnych przez organy administracji rządowej i samorządu terytorialnego oraz miejscową ludność ${ }^{46}$. Pisał:

${ }^{43}$ AAN, MSW, GM - SM, sygn. 817, k. 4-5; Archiwum Państwowe w Kielcach, Urząd Wojewódzki Kielecki, Dyrekcja Robót Publicznych - Wydział Komunikacyjno-Budowlany, sygn. 17103, bp, projekt przepisów miejscowych wojewody kieleckiego w sprawie: 1) czyszczenia kominów w Sosnowcu; 2) zmianie przepisów wodociągowych w Radomiu i Częstochowie; M.P. 1933, nr 116, 296; 1934, nr 125, 127; 1935, nr 17; por. Z. Rudolf, Zadania techniczno-sanitarne $w$ administracji publicznej, „Gazeta Administracji i Policji Państwowej” 1933, nr 18.

${ }_{44}$ AAN, MSW, GMWPO, sygn. 7, k. 245-248; R. Hausner, Pierwsze dwudziestolecie administracji..., s. 20.

${ }_{45}$ M.P. 1935, nr 224; 1938, nr 76; K.W. Kumaniecki, J.S. Langrod, S. Wachholz, Zarys ustroju, postępowania i prawa administracyjnego w Polsce, Warszawa - Kraków 1939, s. 481-482.

${ }^{46}$ APL, UWL, WO, sygn. 274, s. 10. 
Odnawianie i reparacja domów, porządkowanie ulic i dostarczanie im powietrza i słońca przez zastępowanie murów i zwartych płotów ażurowych ogrodzeniami dawało pracę dużej ilości bezrobotnych, zatrudnionych w sposób dorywczy na całą Polskę do 120 tysięcy ludzi [...]. W Łodzi i jej okolicach aż do Zduńskiej Woli, w Tomaszowie, Radomsku, Częstochowie, Zawierciu, Będzinie, Sosnowcu, Warszawie z okolicami, Białymstoku, wreszcie w ośrodku przemysłu naftowego całe dzielnice zmieniły swój wygląd. Wysokie mury, ścieśniające z obu stron wąskie ulice, nieskanalizowane, zakurzone lub zabłocone biegnące do zatruwających powietrze fabryk [...] runęły pod kilofami bezrobotnych. Otwarły się z obu stron dusznych, cuchnących ulic szerokie, powietrzne, przestrzenie zielonych trawników i miłe oku rozrosłe gaje cienistych grup drzew i krzewów, tworzące półkoliste ograniczenia polan, zazdrośnie dotąd zakrywanych w parkach, otaczających pałace właścicieli fabryk. Wysokie przewiewne sztachety lub siatki żelazne, często oplecione dzikim winem, umożliwiały odgrodzenie się właścicieli parków od ruchliwych ulic, bez hamowania dostępu słońca i powietrza do szerokiego widoku i oddechu dla codziennie przechodzących nimi robotników i ich rodzin ${ }^{47}$.

Minister S.F. Składkowski przyznawał, że mniejsze sukcesy w akcji higieniczno-sanitarnej odnosił na terenie wiejskim. Mimo zaangażowania władz administracji ogólnej pierwszej i drugiej instancji, Policji Państwowej i władz samorządowych ludność wiejska opornie przyjmowała nakaz budowy ustępów (sławojek) w swoich obejściach, porządkowania podwórzy, malowania wapnem (bielenia) domostw itp. Minister stwierdzał jednak z przekonaniem:

Lud nasz ma głęboko zakorzeniony instynkt samozachowawczy i nie da się łatwo złapać na lep nowych haseł i porządków. Ale „przyjdzie taki czas”, że sławojka przyjmie się nie tylko w nazwie, ale w swym pełnym i jakże istotnym zastosowaniu $^{48}$.

5. Podsumowując, należy skonstatować, że polityka resortu spraw wewnętrznych w zakresie zdrowia publicznego w pierwszej połowie lat 20 . XX w. koncentrowała się na zwalczaniu epidemii i chorób zakaźnych, zwłaszcza najgroźniejszej z nich - gruźlicy. W tym czasie kierownictwo resortu w ostateczny sposób przejęło nadzór nad szpitalnictwem krajowym, nad powstającymi dopiero otwartymi ośrodkami zdrowia, a w konsekwencji nad całym personelem medycznym i techniczno-administracyjnym. Działało na rzecz podniesienia ogólnego poziomu higieny społecznej poprzez wydawanie różnego rodzaju zarządzeń sanitarnych, np. dotyczących czystości miast (form i sposobów usuwania nieczystości z pla-

\footnotetext{
47 S.F. Składkowski, Nie ostatnie stowo oskarżonego..., s. 211.

48 S.F. Składkowski, Kwiatuszki administracyjne i inne, Warszawa 2005, s. 27.
} 
ców i ulic miejskich). Nadzorowało w skali kraju rozrastającą się sieć aptek i składów farmaceutycznych.

Po maju 1926 r. nową politykę administracyjną w zakresie zdrowia publicznego realizował przede wszystkim piłsudczykowski minister spraw wewnętrznych dr med. S.F. Składkowski, przygotowując autorski program pt. „Podniesienie zdrowotności i wyglądu kraju”. Realizując go, zalecał ludności stosowanie śmietników i ustępów oraz regularne sprzątanie ulic, placów, podwórzy i obejść domów. MSW z sukcesem walczyło z chorobami zakaźnymi, gdyż ich liczba z roku na rok spadała. Pracowało na rzecz zwiększenia „stanu posiadania” w szpitalnictwie i lecznictwie otwartym. Sprawowało nadzór farmaceutyczny nad aptekami oraz szkoliło personel administracji służby zdrowia, głównie w Państwowej Szkole Higieny.

W latach 1930-1932 ministrowie spraw wewnętrznych koncentrowali się na walce z różnego rodzaju chorobami zakaźnymi i społecznymi, propagując m.in. zasady eugeniki. Działali na rzecz utrzymania dotychczasowej sieci placówek służby zdrowia, zwłaszcza szpitali, które w czasie kryzysu gospodarczego coraz bardziej zadłużały się i stawały się nierentowne. Nadzorowali też sprawy farmaceutyczne (apteki, składy apteczne, drogerie itp.). Od 1 lipca 1932 r. z ich kompetencji zostały wyłączone sprawy służby zdrowia, poza niewielkim działem techniki sanitarnej. Dlatego w latach 1932-1935 działalność resortu koncentrowała się na wykonywaniu zadań związanych z zagadnieniami techniczno-sanitarnymi kraju, zwłaszcza w zakresie zabudowy osiedli i zaopatrzenia ludności w wodę.

W latach 1935-1939 polityka administracyjna resortu spraw wewnętrznych wciąż skupiała się na szeroko rozumianych zagadnieniach higieniczno-sanitarnych kraju, których rola i znaczenie wzrosły, gdy premierem i ministrem spraw wewnętrznych został ponownie S.F. Składkowski. Rozpoczął on wielką akcję higieniczno-sanitarną, głównie na wsi, w ramach której propagował stosowanie szeroko rozumianych zasad higieny, tak w życiu osobistym, jak i publicznym.

\author{
THE ADMINISTRATIVE POLICY OF THE MINISTERS \\ OF INTERNAL AFFAIRS OF INDEPENDENT POLAND \\ IN THE FIELD OF PUBLIC HEALTH (1918-1939)
}

\begin{abstract}
The administrative policy of the heads of the Ministry of Internal Affairs of the Second Polish Republic in the field of healthcare between 1918 and 1939 focused on combating epidemics and infectious diseases, especially tuberculosis, which was the most dangerous one among them. Furthermore, its aim was also to raise the general level of social hygiene by issuing various types of sanitary ordinances concerning, e.g. city cleanliness. Moreover, it concentrated on the supervision of the growing network of pharmacies and
\end{abstract}


pharmaceutical companies across the country. After the May Coup in 1926, a new administrative policy in the field of public health was primarily carried out by S.F. Składkowski, the Minister of Internal Affairs, by means of the "Improvement of State Health and Appearance" programme. He propagated the use of garbage cans and lavatories among the population as well as regular cleaning of streets, squares, courtyards, and homesteads. The Ministry's head worked to increase "the inventory" in both hospitals and outpatient care. The administrative personnel of the healthcare service were trained, for the most part, at the State School of Hygiene. Since the $1^{\text {st }}$ of July 1932, matters concerning healthcare were excluded from the competences of the office of the Minister of Internal Affairs except for a small department of sanitary technology. From that time on, the Ministry of Internal Affairs focused on carrying out the tasks related to the technical and sanitary issues of the country, especially in the field of the development of housing estates and supplying water to the population. The significance of all of the aforementioned issues increased in May of 1936 when S.F. Składkowski became the Prime Minister and the Minister of Internal Affairs. He launched a great hygiene and sanitary programme, mainly in the Polish countryside, in which he advocated the application of hygiene principles both in private and public life.

Keywords: administrative policy, public health, Minister of Internal Affairs, infectious diseases, sanitary and hygiene issues 